\title{
ANALISIS KESTABILAN MODEL SEIR UNTUK PENYEBARAN COVID-19 DENGAN PARAMETER VAKSINASI
}

\section{Stability Analysis of SEIR Model for Covid-19 Spread with Vaccination Parameter}

\author{
Miftahul Jannah $^{1^{*}}$, Muhammad Ahsar Karim², Yuni Yulida ${ }^{3}$ \\ 1,2,3 Prodi Matematika, Fakultas MIPA, Universitas Lambung Mangkurat \\ Jln. Jend. A. Yani km.36, Banjarbaru, 70714, Kalimatan Selatan, Indonesia
}

Corresponding author e-mail: 1*1711011120009@mhs.ulm.ac.id

\begin{abstract}
Abstrak
Covid-19 adalah penyakit menular yang disebabkan oleh coronavirus disease jenis baru, yaitu SARS-CoV-2. Oleh WHO, penyebaran Covid-19 telah ditetapkan sebagai pandemi global sejak 11 Maret 2020. Pada penelitian ini, penyebaran Covid-19 dimodelkan dengan menggunakan model matematika epidemik, yaitu model SEIR (Susceptible, Exposed, Infected, and Recovered) dengan memperhatikan faktor vaksinasi sebagai parameter. Selanjutnya, ditentukan titik ekuilibrium dan bilangan reproduksi dasar, serta diberikan analisis kestabilan pada model.
\end{abstract}

Kata Kunci : Covid-19, Model SEIR, Parameter Vaksinasi, Bilangan Reproduksi Dasar, Analisis Kestabilan.

\begin{abstract}
Covid-19 is an infectious disease caused by a new type of coronavirus disease, namely SARS-CoV-2. By WHO, the spread of Covid-19 has been designated as a global pandemic since March 11, 2020. In this study, the spread of Covid-19 was modeled using an epidemic mathematical model, namely the SEIR (Susceptible, Exposed, Infected, and Recovered) model by taking into account the vaccination factor as parameter. Next, the equilibrium point and the basic reproduction number are determined, and stability analysis is given to the model.
\end{abstract}

Keywords: Covid-19, SEIR Model, Vaccination Parameters, Basic Reproductive Numbers, Stability Analysis. 


\section{PENDAHULUAN}

Sejumlah besar wabah penyakit telah terjadi dalam sejarah manusia dan menyebabkan jutaan orang kehilangan nyawa mereka. Beberapa penyakit telah membuat ribuan orang sekarat setiap tahunnya dan kemudian penyakit tersebut menjadi endemik [1]. Dalam dua dekade terakhir, ada dua epidemi virus Corona yang telah dilaporkan. Epidemi virus Corona pertama dikenal sebagai SARS, yang telah menyebar mulai dari China hingga ke 25 negara lainnya dan menginfeksi lebih dari 8.000 individu dengan 800 kematian $[1,12]$. Epidemi virus Corona yang kedua disebut MERS, yang menyebar dari Saudi Arabia ke sejumlah negara lain, dengan sekitar 25.000 individu terinfeksi dan oleh karenanya ribuan orang kehilangan nyawa [1]. Kemudian, pada akhir Desember 2019, kasus pneumonia misterius pertama kali dilaporkan di Wuhan, Provinsi Hubei, China. Penyebab utama infeksi ini adalah virus Corona baru, yang kemudian dikenal dengan Covid-19 [1, 2].

Covid-19 adalah penyakit menular yang disebabkan oleh Coronavirus jenis baru yang kemudian diberi nama Severe Acute Respiratory Syndrome Coronavirus 2 (SARS-CoV-2) [2]. SARS-CoV-2 berasal dari keluarga yang sama dengan virus penyebab SARS dan MERS. Meskipun berasal dari keluarga yang sama, tetapi virus ini lebih menular dibandingkan dengan SARS-CoV dan MERS-CoV. Pada tanggal 30 Januari 2020, WHO menetapkan kejadian tersebut sebagai Kedaruratan Kesehatan Masyarakat yang Meresahkan Dunia (KKMMD)/ Public Health Emergency of International Concern (PHEIC). Kemudian pada tanggal 11 Maret 2020, WHO resmi menetapkan Covid-19 sebagai pandemi global [6].

Adanya pandemi Covid-19 membuat para peneliti tertarik melakukan kajian lebih mendalam dari segi epidemiologi. Para peneliti menggunakan berbagai cara untuk memahami mekanisme penularan penyakit Covid-19 di dalam masyarakat dan cara mengurangi serta mengendalikannya. Salah satu cara yang dapat memberikan penjelasan dan pemahaman tentang mekanisme tersebut adalah melalui pemodelan matematika.

Model matematika adalah suatu alat yang dapat berperan dalam mempelajari penyebaran penyakit, biasa disebut model matematika epidemiologi. Model klasik tentang penyebaran penyakit telah dirumuskan oleh Kermack pada tahun 1927, yang dikenal dengan model SIR (Infected, Susceptible, and Recovered). Pada model SIR, populasi total dibagi menjadi 3 subpopulasi, yaitu Susceptible yang menyatakan jumlah individu sehat tetapi rentan terinfeksi penyakit, Infected yang menyatakan jumlah individu yang terinfeksi dan dapat menularkan penyakit, dan Recovered yang menyatakan subpopulasi yang sembuh. Beberapa penyakit memiliki periode laten (masa inkubasi), yaitu selang waktu individu sehat menjadi individu yang terinfeksi dan dapat menularkan penyakit. Periode tersebut mengakibatkan munculnya subpopulasi baru, yaitu Exposed. Dengan penambahan tersebut, model SIR dikembangkan dan menjadi model SEIR [14].

Covid-19 diketahui memiliki periode laten, yaitu sekitar 5 - 6 hari dengan range antara 1 - 14 hari [6]. Oleh karena itu, penyebaran Covid-19 dapat dikaji dengan menggunakan model SEIR. Di sisi lain, penanganan penyebaran Covid-19 melibatkan adanya vaksinasi, sehingga dalam pemodelan perlu memperhatikan faktor vaksinasi tersebut. Dengan demikian, pada penelitian ini dikaji penyebaran Covid-19 dengan menggunakan model SEIR dan melibatkan faktor vaksinasi sebagai parameter. Secara umum, kajian ini berisi tentang penentuan titik ekuilibrium dan bilangan reproduksi dasar, analisis kestabilan, dan simulasi dari model.

\section{METODE PENELITIAN}

Penelitian ini diawali dengan studi pustaka dan literatur untuk membangun model matematika yang merepresentasikan dinamika penyebaran Covid-19 pada populasi [1, 7, 10, 11, dan 15]. Beberapa metode yang digunakan untuk mengkaji model SEIR dengan parameter vaksinasi adalah matriks Next Generation, linearisasi, analisis kestabilan, metode Runge Kutta, dan simulasi numerik untuk visualisasi solusi model.

\section{HASIL DAN PEMBAHASAN}

\subsection{Pembentukan Model}

Model SEIR untuk penyebaran Covid-19 dengan parameter vaksinasi terdiri dari empat kompartemen, yaitu subpopulasi Susceptible (S), Exposed (E), Infected (I) dan Recovered (R), sebagaimana digambarkan melalui diagram alir pada Gambar 1. 
$v$

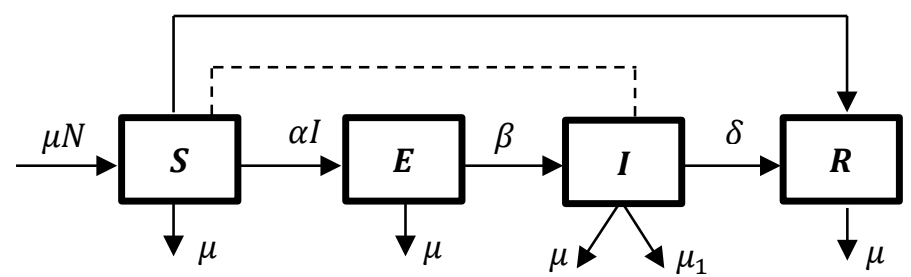

Gambar 1. Diagram Alir Model SEIR untuk Penyebaran Covid-19

Model SEIR pada Gambar 1 dapat dinyatakan dalam sistem persamaan diferensial nonlinier berikut:

$\frac{d S}{d t}=\mu N-\left(\frac{\alpha I}{N}+\mu+v\right) S$

$\frac{d E}{d t}=\frac{\alpha I S}{N}-(\beta+\mu) E$

$\frac{d I}{d t}=\beta E-\left(\mu_{1}+\delta+\mu\right) I$

$\frac{d R}{d t}=\delta I+v S-\mu R$

dengan deskripsi variabel dan parameter model diberikan pada Tabel 1.

Tabel 1. Deskripsi variabel dan parameter model SEIR untuk penyebaran Covid-19

\begin{tabular}{ccl}
\hline $\begin{array}{c}\text { Variabel/ } \\
\text { Parameter }\end{array}$ & \\
\hline$t$ & $:$ & Kaktu. \\
\hline$S(t)$ & $:$ & Seterangan \\
\hline$E(t)$ & $:$ & Subpopulasi terpapar terhadap penyakit pada waktu $t$. \\
\hline$I(t)$ & $:$ & Subpopulasi terinfeksi terhadap penyakit pada waktu $t$. \\
\hline$R(t)$ & $:$ & Subpopulasi sembuh atau yang telah divaksinasi terhadap penyakit pada waktu $t$. \\
\hline$N(t)$ & $:$ & Populasi, yaitu $N(t)=S(t)+E(t)+I(t)+R(t)$. \\
\hline$\mu$ & $:$ & Laju kelahiran/kematian. \\
\hline$\alpha$ & $:$ & Laju kontak individu Susceptible dengan individu Infected. \\
\hline$\beta$ & $:$ & Laju aktivasi virus. \\
\hline$\mu_{1}$ & $:$ & Laju kematian akibat terinfeksi Covid-19. \\
\hline$\delta$ & $:$ & Laju kesembuhan individu yang terinfeksi Covid-19. \\
\hline$v$ & $:$ & Laju pemberian vaksin.
\end{tabular}

Misalkan

$$
s=\frac{S}{N} ; e=\frac{E}{N} ; i=\frac{I}{N} ; r=\frac{R}{N}
$$

dengan $n=s+e+i+r=1$. Model pada Persamaan (1) - (4) dapat dinyatakan sebagai berikut:

$$
\begin{aligned}
& \frac{d s}{d t}=\mu-(\alpha i+\mu+v) s \\
& \frac{d e}{d t}=\alpha i s-(\beta+\mu) e \\
& \frac{d i}{d t}=\beta e-\left(\mu_{1}+\delta+\mu\right) i \\
& \frac{d r}{d t}=\delta i+v s-\mu r
\end{aligned}
$$




\subsection{Titik Ekulibrium dan Bilangan Reproduksi Dasar}

Titik ekuilibrium dari Persamaan (5) - (8) dapat ditentukan dengan memenuhi kondisi [13]:

$$
\frac{d s}{d t}=0 ; \frac{d e}{d t}=0 ; \frac{d i}{d t}=0 \text { dan } \frac{d r}{d t}=0 .
$$

Oleh karena itu, diperoleh

$$
\begin{aligned}
& \mu-(\alpha i+\mu+v) s=0 \\
& \alpha i s-(\beta+\mu) e=0 \\
& \beta e-\left(\mu_{1}+\delta+\mu\right) i=0 \\
& \delta i+v s-\mu r=0
\end{aligned}
$$

\subsubsection{Titik Ekuilibrium Bebas Penyakit}

Titik ekuilibrium bebas penyakit $\left(E_{0}\right)$ adalah kondisi dimana tidak terdapat individu yang terinfeksi Covid-19 pada suatu populasi, yaitu saat $e=i=0$. Dengan menyelesaikan Persamaan (9) - (12) diperoleh:

$$
E_{0}=(s, e, i, r)=\left(\frac{\mu}{\mu+v}, 0,0, \frac{v}{\mu+v}\right) .
$$

\subsubsection{Bilangan Reproduksi Dasar}

Bilangan reproduksi dasar, yang dinotasikan dengan $\left(R_{0}\right)$ ditentukan untuk mengetahui dinamika penyebaran penyakit. $R_{0}$ merupakan jumlah rata-rata individu infeksi sekunder akibat tertular individu infeksi primer yang masuk sepenuhnya ke dalam subpopulasi rentan. $R_{0}$ dapat ditentukan dengan menggunakan metode Next Generation Matrix [9].

Misalkan $\boldsymbol{x}=\left(\begin{array}{l}e \\ i\end{array}\right) \in \mathbb{R}^{2}$ menyatakan subpopulasi terinfeksi dari Persamaan (9)-(12). Selanjutnya diperoleh,

$$
\frac{d \boldsymbol{x}}{d t}=\mathcal{F}-\mathcal{V}=\left(\begin{array}{c}
\alpha i s \\
\beta e
\end{array}\right)-\left(\begin{array}{c}
(\beta+\mu) e \\
\left(\mu_{1}+\delta+\mu\right) i
\end{array}\right)
$$

Jacobian dari matriks di atas direpresentasikan oleh

$$
D \mathcal{F}=\left(\begin{array}{cc}
0 & \alpha s \\
\beta & 0
\end{array}\right) \text { dan } D \mathcal{V}=\left(\begin{array}{cc}
(\beta+\mu) & 0 \\
0 & \left(\mu_{i}+\delta+\mu\right)
\end{array}\right) .
$$

Kemudian, titik ekuilibrium $E_{0}$ disubtitusi sehingga diperoleh

$$
F=\left(\begin{array}{cc}
0 & \frac{\alpha \mu}{\mu+v} \\
\beta & 0
\end{array}\right) ; V=\left(\begin{array}{cc}
(\beta+\mu) & 0 \\
0 & \left(\mu_{1}+\delta+\mu\right)
\end{array}\right)
$$

Matriks Next Generation diperoleh sebagai berikut:

$$
G=F V^{-1}=\left(\begin{array}{cc}
0 & \frac{\alpha \mu}{(\mu+v)\left(\mu_{1}+\delta+\mu\right)} \\
\frac{\beta}{(\beta+\mu)} & 0
\end{array}\right) .
$$

Karena $R_{0}$ merupakan nilai eigen dominan dari matriks $G\left(G=\rho\left(F V^{-1}\right)\right)$ [9], maka diperoleh bilangan reproduksi dasar dari model SEIR untuk penyebaran Covid-19 dengan parameter vaksinasi adalah

$$
R_{0}=\frac{\alpha \beta \mu}{(\beta+\mu)(\mu+v)\left(\mu_{1}+\delta+\mu\right)}
$$

\subsubsection{Titik Ekuilibrium Endemik}

Pada bagian ini, untuk menentukan titik ekuilibrium endemik dari model dapat dilakukan dengan menyelesaikan Persamaan (9) - (12), untuk $i \neq 0$. Dengan demikian, diperoleh titik ekuilibrium endemik pada model ini adalah: 


$$
E^{*}=\left(s^{*}, e^{*}, i^{*}, r^{*}\right)=\left(\frac{\mu}{R_{0}(\mu+v)}, \frac{\mu\left(R_{0}-1\right)}{R_{0}(\beta+\mu)}, \frac{(\mu+v)\left(R_{0}-1\right)}{\alpha}, \frac{\delta\left(R_{0}-1\right) R_{0}(\mu+v)^{2}+\alpha \mu v}{\alpha \mu R_{0}(\mu+v)}\right)
$$

dengan syarat $R_{0}>1$.

\subsection{Analisis Kestabilan Model}

Berdasarkan Persamaan (5) - (8), dapat ditentukan matriks Jacobian [8] sebagai berikut:

$$
J=\left(\begin{array}{cccc}
-(\alpha i+\mu+v) & 0 & -\alpha s & 0 \\
\alpha i & -(\beta+\mu) & \alpha s & 0 \\
0 & \beta & -\left(\mu_{1}+\delta+\mu\right) & 0 \\
v & 0 & \delta & -\mu
\end{array}\right)
$$

\subsubsection{Kestabilan Model di Titik Ekuilibrium Bebas Penyakit}

Berdasarkan matriks Jacobian pada Persamaan (14), selanjutnya ditentukan kestabilan model di titik ekuilibrium bebas penyakit $\left(E_{0}\right)$.

Teorema 1. Titik ekuilibrium bebas penyakit $\left(E_{0}\right)$ dari Persamaan (5)-(8) stabil asimtotik lokal pada saat $R_{0}<1$.

Bukti. Matriks Jacobian di persekitaran titik ekuilibrium $E_{0}$ adalah

$$
J_{E_{0}}=\left(\begin{array}{cccc}
-(\mu+v) & 0 & \frac{-\alpha \mu}{\mu+v} & 0 \\
0 & -(\beta+\mu) & \frac{\alpha \mu}{\mu+v} & 0 \\
0 & \beta & -\left(\mu_{1}+\delta+\mu\right) & 0 \\
v & 0 & \delta & -\mu
\end{array}\right)
$$

Dengan menggunakan persamaan karakteristik [5], yaitu

$\left|J_{E_{0}}-\lambda I\right|=(\mu+\lambda)(\mu+v+\lambda)\left\{(\beta+\mu+\lambda)\left(\mu_{1}+\delta+\mu+\lambda\right)-\frac{\alpha \beta \mu}{\mu+v}\right\}=0$,

Maka diperoleh nilai eigen sebgai berikut:

$$
\lambda_{1}=-\mu<0 ; \lambda_{2}=-(\mu+v)<0,
$$

atau

$(\beta+\mu+\lambda)\left(\mu_{1}+\delta+\mu+\lambda\right)-\frac{\alpha \beta \mu}{\mu+v}=0$

Persamaan (15) digunakan untuk menentukan nilai $\lambda_{3}$ dan $\lambda_{4}$, yaitu

$a_{0} \lambda^{2}+a_{1} \lambda+a_{2}=0$.

dengan:

$a_{0}=1>0$,

$a_{1}=\mu_{1}+\beta+\sigma+2 \mu>0$,

$a_{2}=(\beta+\mu)\left(\mu_{1}+\delta+\mu\right)-\left(\frac{\alpha \beta \mu}{\mu+v}\right)=(\beta+\mu)\left(\mu_{1}+\delta+\mu\right)\left(1-R_{0}\right)>0$, jika $R_{0}<1$.

Berdasarkan Persamaaan (16), dengan menggunakan kriteria Routh-Hurwizt [3] dapat diketahui bahwa bagian riil dari $\lambda_{3}$ dan $\lambda_{4}$ bernilai negatif dengan syarat $R_{0}<1$. Kemudian, karena bagian riil $\lambda_{1}, \lambda_{2}, \lambda_{3}$, dan $\lambda_{4}$ bernilai negatif, maka berdasarkan Teorema Kestabilan [8] diperoleh bahwa titik ekuilibrium bebas penyakit adalah stabil asimtotik, dengan syarat $R_{0}<1$.

\subsubsection{Kestabilan Model di Titik Ekuilibrium Endemik}

Kestabilan model di titik ekuilibrium endemik $\left(E^{*}\right)$ ditentukan sebagai berikut.

Teorema 2. Titik ekuilibrium endemik $\left(E^{*}\right)$ dari Persamaan (5)-(8) stabil asimtotik lokal pada saat $R_{0}>1$. 
Bukti. Dengan menggunakan titik ekulibrium $E^{*}$ dan matriks Jacobian pada Persamaan (14), maka diperoleh

$$
J_{E^{*}}=\left(\begin{array}{cccc}
-\left((\mu+v) R_{0}\right) & 0 & \frac{-\alpha \mu}{R_{0}(\mu+v)} & 0 \\
(\mu+v)\left(R_{0}-1\right) & -(\beta+\mu) & \frac{\alpha \mu}{R_{0}(\mu+v)} & 0 \\
0 & \beta & -\left(\mu_{1}+\delta+\mu\right) & 0 \\
v & 0 & \delta & -\mu
\end{array}\right)
$$

Dengan menggunakan persamaan karakteristik [5], yaitu

$$
\left|J_{E^{*}}-\lambda I\right|=(\mu+\lambda)\left\{\left[\left((\mu+v) R_{0}+\lambda\right)(\beta+\mu+\lambda)\left(\mu_{1}+\delta+\mu+\lambda\right)\right]-\left[\frac{\alpha \beta \mu}{R_{0}}+\frac{\alpha \beta \mu \lambda}{R_{0}(\mu+v)}\right]\right\}=0
$$

maka diperoleh nilai eigen berikut:

$$
\lambda_{1}=-\mu<0,
$$

atau

$\left[\left((\mu+v) R_{0}+\lambda\right)(\beta+\mu+\lambda)\left(\mu_{1}+\delta+\mu+\lambda\right)\right]-\left[\frac{\alpha \beta \mu \lambda}{R_{0}(\mu+v)}+\frac{\alpha \beta \mu}{R_{0}}\right]=0$

Dari Perssamaan (17), dimisalkan:

$A=\left((\mu+v) R_{0}\right)>0$;

$B=(\beta+\mu)>0$;

$C=\left(\mu_{1}+\delta+\mu\right)>0$

$D=\frac{\alpha \beta \mu}{R_{0}(\mu+v)}>0$; dan

$E=\frac{\alpha \beta \mu}{R_{0}}>0$, sehingga diperoleh:

$a_{0} \lambda^{3}+a_{1} \lambda^{2}+a_{2} \lambda+a_{3}=0$,

dengan:

$a_{0}=1>0$

$a_{1}=(A+B+C)>0$

$a_{2}=A B+A C+B C-D$;

$a_{3}=(A B C-E)>0$, jika $R_{0}>1$.

Berdasarkan Persamaaan (18), dengan menggunakan kriteria Routh-Hurwizt [3] dapat diketahui bahwa bagian riil dari $\lambda_{2}, \lambda_{3}$, dan $\lambda_{4}$ bernilai negatif dengan syarat $R_{0}>1$. Kemudian, karena bagian riil $\lambda_{1}, \lambda_{2}, \lambda_{3}$, dan $\lambda_{4}$ bernilai negatif, maka berdasarkan Teorema Kestabilan [8] diperoleh bahwa titik ekuilibrium endemik adalah stabil asimtotik, dengan syarat $R_{0}>1$.

\subsubsection{Simulasi Titik Ekuilibrium Bebas Penyakit}

Simulasi titik ekuilibrium $E_{0}(s, e, i, r)$ dapat ditentukan dengan memberikan nilai awal dan beberapa parameter yang memenuhi syarat $R_{0}<1$. Parameter yang digunakan pada simulasi di titik ekulibrium bebas penyakit diberikan pada Tabel 2, dengan interval $[0,600]$ dan $h=0,1$.

Tabel 2. Parameter yang digunakan pada simulasi di titik ekuilibrium bebas penyakit

\begin{tabular}{cccccc}
\hline $\boldsymbol{\alpha}$ & $\boldsymbol{\beta}$ & $\boldsymbol{\mu}$ & $\boldsymbol{\mu}_{\mathbf{1}}$ & $\boldsymbol{\delta}$ & $\boldsymbol{v}$ \\
\hline $0,62 \times 10^{-8}$ & $7,14 \times 10^{-2}$ & $6,25 \times 10^{-3}$ & $6,667 \times 10^{-4}$ & $7,344 \times 10^{-7}$ & 0,01 \\
\hline
\end{tabular}


Simulasi untuk titik ekuilibrium $E_{0}$ dapat dilihat pada Gambar 2 berikut ini.

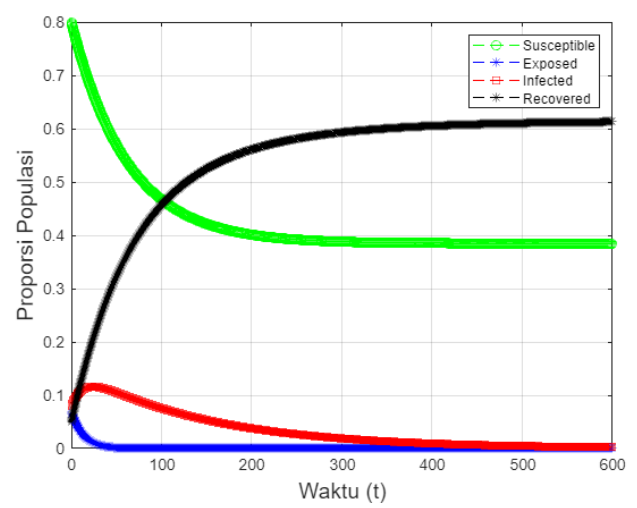

Gambar 2. Simulasi Titik Ekuilibrium $E_{0}$

\subsubsection{Simulasi Titik Endemik}

Simulasi titik ekuilibrium endemik $E^{*}(s, e, i, r)$ dapat ditentukan dengan memberikan nilai awal dan beberapa parameter yang memenuhi syarat $R_{0}>1$. Parameter yang digunakan pada simulasi di titik ekulibrium endemik diberikan pada Tabel 3, dengan interval $[0,1000]$ dan $h=0$.

Tabel 3. Parameter yang digunakan pada simulasi di titik ekuilibrium 541ndemic

\begin{tabular}{cccccc}
\hline $\boldsymbol{\alpha}$ & $\boldsymbol{\beta}$ & $\boldsymbol{\mu}$ & $\boldsymbol{\mu}_{\mathbf{1}}$ & $\boldsymbol{\delta}$ & $\boldsymbol{v}$ \\
\hline 0,62 & $7,14 \times 10^{-2}$ & $6,25 \times 10^{-3}$ & $6,667 \times 10^{-4}$ & $7,344 \times 10^{-3}$ & 0,08 \\
\hline
\end{tabular}

Simulasi untuk titik ekuilibrium $E^{*}$ dapat dilihat pada Gambar 3 berikut ini.

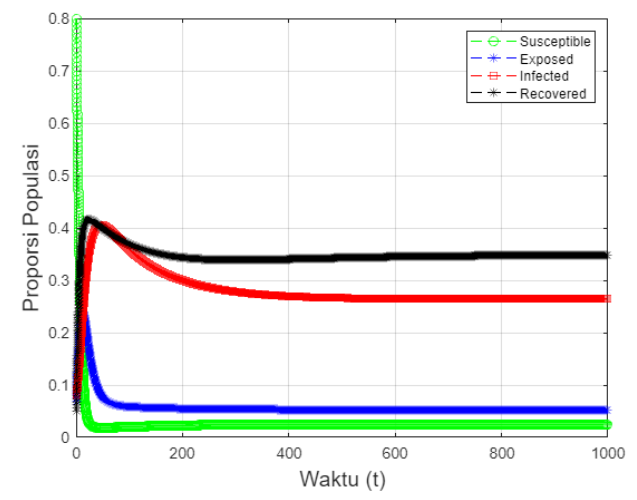

Gambar 3. Simulasi Titik Ekuilibrium $E^{*}$

\section{KESIMPULAN}

Berdasarkan model SEIR untuk penyebaran Covid-19 dengan memperhatikan vaksinasi sebagai parameter model, maka diperoleh bilangan reproduksi dasar $R_{0}=\frac{\alpha \beta \mu}{(\beta+\mu)(\mu+v)\left(\mu_{1}+\delta+\mu\right)}$, titik ekuilibrium bebas penyakit $E_{0}=\left(\frac{\mu}{\mu+v}, 0,0, \frac{v}{\mu+v}\right)$ yang stabil asimtotik lokal pada saat $R_{0}<1$, dan titik ekuilibrium endemik $E^{*}=\left(\frac{\mu}{R_{0}(\mu+v)}, \frac{\mu\left(R_{0}-1\right)}{R_{0}(\beta+\mu)}, \frac{(\mu+v)\left(R_{0}-1\right)}{\alpha}, \frac{\delta\left(R_{0}-1\right) R_{0}(\mu+v)^{2}+\alpha \mu v}{\alpha \mu R_{0}(\mu+v)}\right)$ yang juga stabil asimtotik lokal pada saat $R_{0}>1$. Hal ini didukung melalui simulasi numerik yang memberikan visualisasi bahwa titik ekuilibrium $E_{0}$ dan $E^{*}$ masing-masing stabil asimtotik lokal. 


\section{DAFTAR PUSTAKA}

[1] Abdullah, S. Ahmad, S. Owyed, A.H. Abdel-Aty, E.E. Mahmoud, K. Shah and H. Alrabaiah,"Mathematical analysis of COVID19 via new mathematical model," Chaos, Salitons and Fractals, vol.143, no.110585, pp.1-9, December 2020.

[2] A. Susilo, C.M. Rumende, C.W. Pitoyo, W.D. Santoso, M. Yulianti, Herikurniawan, R. Sinto, G. Singh, L. Nainggolan, E.J. Nelwan, L.K. Chen, A. Wildhani, E. Wijaya, B. Wicaksana, M. Maksum, F. Annisa, C.O.M. Jasirwan, E. Yunihastuti, "Coronavirus disease 2019: tinjauan literatur terkini," Jurnal Penyakit Dalam Indonesia, vol. 7, no. 1, pp. 45-67, Maret 2020.

[3] F. R. Gantmacher, The Theory of Matrices. USA : American Mathematical Society, 2000.

[4] Fardinah, "Solusi Persamaan Diferensial Biasa dengan Metode Runge-Kutta Orde Lima," Jurnal MSA, vol.5, no.1, pp.1-7, Juni 2017.

[5] H. Anton, C. Rorress, and A. Kaul, Elementary Linear Algebra Application Version, 12th Edition. USA: John Wiley \& Sons Inc, 2019.

[6] Kementrian Kesehatan RI, Pedoman Pencegahan dan Pengendalian Coronavirus Disease (Covid-19). Jakarta, Indonesia: Kementrian Kesehatan RI, 2020.

[7] M.A. Karim, and Y. Yulida, "Analisa Pelaksanaan New Normal di Kalimantan Selatan melalui Model Matematika SIRD," Media Bina Ilmiah (MBI), vol. 14, no. 12, pp. 3681-3688, Juli 2020

[8] N. Bellomo, and L.Preziosi, Modelling Mathematical Methods and Scientific Computation, Florida : CRC Press,1995.

[9] P. Driessche. van den and J. Watmough, "Reproduction Numbers and Sub-threshold Endemic Equilibria for Compartmental Models of Disease Transmission," Mathematical Biosciences,vol. 180, pp. 29-48, June 2002.

[10] S. Annas, M.I. Pratama, M. Rifandi, W. Sanusi and S. Side, "Stability analysis and numerical simulation of SEIR model for pandemic COVID-19 spread in Indonesia," Chaos, Salitons and Fractals, vol. 139, no. 110072, pp. 1-7, July 2020.

[11] S. L. Ross, Differential Equation, 3th Edition. New Delhi: John Wiley and Sons, 2004.

[12] S. Osler, Coronavirus Outbreak: All the secrets revealed about the Covid-19 pandemic. A Complete Rational Guide of its, Evolution, Expansion, Symptoms and First Defense. America : Sidney Osler, 2019.

[13] S. Wiggins, Introduction To Applied Nonlinear Dynamical Systems And Chaos. New Delhi: Springer-Verlag, 2003.

[14] W.D. Sihotang, C.C. Simbolon, J. Hartiny, D. Tindaon, L.P. Sinaga, “Analisis Kestabilan Model SEIR Penyebaran Penyakit Campak dengan Pengaruh Imunisasi dan Vaksin MR,” Jurnal Matematika, Statistika \& Komputasi (JMSK), vol. 16, no. 1, pp. 107-113, July 2019.

[15] Y. Yulida, and M.A. Karim, "Pemodelan Matematika Penyebaran Covid-19 di Provinsi Kalimantan Selatan", Media Bina Ilmiah (MBI), vol.14, no. 10, pp. 3257-3264, Mei 2020. 
